\title{
PROBLEM INSIDER DAN OUTSIDER DALAM STUDI AGAMA PERSPEKTIF RUSSEL T. MCCUTCHEON
}

\author{
Rusdin \\ STAIN Datokarama Palu Jl. Diponegoro 23 Palu \\ E-mail: rusdin_ahmad@yahoo.com
}

\begin{abstract}
Abstrak: Russel T. McCutheon, tokoh yang kritis dalam melihat dan merespon persoalan agama ini, memberikan pandangan bahwa dalam menghadapi kehidupan yang serba canggih dan modern, perlu digunakan berbagai multi pendekatan sehingga menghasilkan sebuah teori yang bisa dipahami dan diterima oleh seluruh umat beragama. Selain itu, tidak akan ada yang merasa termarjinalkan dari struktur kehidupan sosial sebab dunia yang dihuni oleh manusia imi kadang-kadang membuat dirinya merasa lebih berkuasa dari penguasa yang sebenrnya. Russel $T$. McCutheon memberikan contoh Amerika Utara dan Eropa setiap saat ada perubahan dalam struktur pemahaman dan budaya masyarakat sebab kedua wilayah ini memiliki karakter dan budaya yang berbeda-beda, maka secara antropologis harus dilakukan pendekatan atau cara memahami karakter dan perilaku masyarakat dan agamanya secara keseluruhan.
\end{abstract}

Abstract: Russel T. McCutheon, a critical figure in studying and responding to the issue of religion, argued that in dealing with a modern and sophisticated life, a variety of approaches must be used to produce a theory that can be understood and accepted by all religions. In addition, no one would have felt marginalized from the structure of social life as the world inhabited by human beings sometimes makes them feel more powerful than the actual ruler. McCutheon gives an example of America and Europe in which considerable change in the structure of the understanding and culture of the community occurs because both regions have different characters and cultures. Thus, an anthropological approach to understand the character and behavior of the society and religion as a whole is necessary.

Kata Kunci: insider, outsider, studi agama, Russel T. McCutcheon 


\section{PENDAHULUAN}

Persoalan Agama merupakan fenomena yang tidak terlepas dari sejarah perjalanan kehidupan manusia. Setidaknya ada 5 agama besar berbeda yang mempunyai penganut di seluruh dunia $^{1}$. Agama-agama ini tumbuh dan berkembang sebagaimana yang disampaikan oleh penganutnya secara turun-temurun. Walaupun secara garis besar agama-agama ini mempunyai aspekaspek yang sama sekaligus berbeda, misalnya sistem keimanan, ritual, norma, dan sebagainya.

Begitu pula sifatnya ada yang inklusif, pluralis, ada pula yang eksklusif, konservatif; ada yang missionary dan ada pula yang non-missionary. Penelitian agama perlu dilakukan untuk mengetahui fenomena agama dalam kehidupan dan mengetahui perbedaan antaragama agar dapat menentukan sikap yang seharusnya diambil oleh penganut agama masing-masing. Dalam tulisan ini penulis ingin menyampaikan beberapa pemikiran keagmaan kaitannya dengan masalah studi agama-agama (study of religons), baik dari kalangan Islam (insider) dan di luar Islam (outsider), seperti halnya diungkapkan oleh Muhammad Abdul Rauf "The Puture of The Islamic Tradition North America, ${ }^{2}$ Masa depan tradisi Islam di Amerika utara yang ramah bersahabat terhadap seluruh masyarakat Amerika, yang sebagian besar telah didominasii oleh tradisi Yahudi-Kristen, dalam beberapa dekade terakhir ini. Berdasarkan pengamatan Muhammad Abdull Rauf, eksistensi Islam khususnya di Amerika Utara, telah mengalami berbagai macam degradasi dan tantangan khususnya masalahmasalah tradisi keisalaman, yang selama ini dianggap telah menyatu dengan warga Amerika lainnya.

${ }^{1} J o e s o e f$ Sou'yb, Agama-Agama Besar Dunia (Jakarta Al-Husna Zikra, 1996), h. 12.

${ }^{2}$ Muhammad Abdul Rauf, The Muslim Community in North Amerika, Earle H. Waugh, Baha Abu-Laban, Regula Qureshi, 1983), h. i. 
Para peneliti agama telah memberikan argumentasi masingmasing misalnya teori tentang sifat dan asal usul agama "Many theorieas about the nature and origin of rligion try to account for the persistence of faith and ritua $\beta$ dalam kutipan ini pada dasarnya ahli peneliti agama khususnya orang yang diluar Islam (outsider) kadang-kadang problem yang dihadapi masing-masing agama tidak nyambung apa sebenarnya yang menyebabkan sehingga orang-orang Islam (insider) yang ada di Amerika utara merasakan ada sesuatu yang sangat mengganggu, bukan persoalan teori atau ukuran keiaman masing-masing keyakinan, melainkan bagaimana jalan keluarnya, sehingga keberadaan Islam dapat merasa aman, bahkan mereka (outsider) kembali mengatakana, "They also explore reason for the changes that religions have andergone in the course of their history ${ }^{4}$ (mereka juga mengeksplorasi alasanalasan untuk sebuah perubahan yang telah dianggap tidak menguntungkan kaitannya dengan proses sejarah agama mereka). Inilah sebenarnya Muhammad Abdul Rauf merasa prihatin terhadap pola pikir dan pengetahuan para ahli agama yang ada di wilayah itu. Abdul Rauf kembali mengatakan "kajian-kajian linguistik historis yang dilakukan di Barat atas materi-materi keislaman kadang-kadang sangat berlebihan bahkan menganggap Islam hanya sebuah tradisi ${ }^{5}$ yang tidak memiliki nilai dan subtansi. Meskipun dalam pandangan Fazlur Rahman agak berbeda sebagaimana kajian keislaman yang dilakukan oleh outsider dapat sama absahnya yang dilakukan oleh insider kajian outsider yang dijalankan tanpa prasangka apa yang disebut open method dan memiliki kriteria keilmuan yang layak (knowledge) ${ }^{6}$ yang dapat dipertanggungjawabkan.

${ }^{3}$ Edited By Russel T. McCuteheon, The Insider/Outsider, Problem in the Study of Religion, (Lexington Avenus New York Prist Published, 1999), h. 114115.

${ }^{4}$ Ibid.

${ }^{5}$ Muhammad Abdul Rauf, Insider/Outsider Preventives in Islamic Studies (UIN Sunan Kalijaga Jogyakarat, 2009), h. 82.

${ }^{6}$ Muhammad Abdul Rauf, The Muslim Community..., h. 445. 
Pada dasarnya Fazlur Rahman mengajak para ahli peneliti agama melakukan pertemuan (Islah) dalam rangka membicarakan masing-masing agama sepertri "para intelektual tidak hanya memiliki sejenis pengetahuan ilmiah tetapi juga akan memungkinkan bagi insider dan outsider untuk saling bertukar pikiran dan kerjasama lewat pemahaman inteletual, sebab dengan dialog masing-masing agama akan melahirkan kesadaran spiritual yang tinggi.

Dari ilustrasi di atas maka timbul pertanyaan apa yang kita ingin capai dalam problem kajian keagamaan terutama di beberapa wilayah dunia dalam pandangan para ahli peneliti dan pengkaji agama-agama (insider dan outsider)?

Untuk memahami problem studi keagamaan yang berkembang di zaman modern ini, perlu dilakukan pengkajian dan pendalaman secara intensif, sistematis, dan komprehensip, sehingga teori-teori baru yang dianggap mampu mengakomodasi isu-iss teologi normatif yang kaku, tekstual, dan fundamental ke arah teologi yang lebih mapan rasional dan pluralis.

Dari background persoalan di atas penulis memfokuskan pada permasalahan tentang bagaimana metodologi keagamaan ketika menghadapi problem global sosial keagamaan?

\section{ANALISIS TEORITIS}

Dalam tulisan ini digunakan beberapa kerangka teori yang terkait dengan persoalan-persoalan keagamaan (problem study of religion) khususnya dalam kehidupan modern. Peter Antes misalanya dalam bukunya berjudul "New Approaches to the Study of Religion: Textual, Comparative, Sociological, and Cognitive" (Pendekatan Baru untuk Studi Agama: Tekstual, Komparatif, Sosiologis, dan Kognitif) hal ini menjelaskan bahwa dalam menghadapi perubahan, khususnya masalah studi keagamaan memerlukan beberapa metode dan pendekatan, sebagai langka menyesuaikan diri dalam mengahadapi berbagai perubahan dan struktur sosial kehidupan masyarakat modern. Dalam 
pengantarnya diungkapkan pendekatan baru untuk studi agama melengkapi survei studi perbandingan agama di abad keduapuluh dengan fokus pada dua dekade terakhir, dan menunjukkan jalan untuk pendekatan masa depan ${ }^{7}$. Meskipun teori ini mendapatkan kritikan oleh Russel T. McCutcheon ${ }^{8}$, mengatakan bahwa perdekatan para ahli studi keagamaan persoalannya karena perbedaan pandangan (paradigma) atau persepsi terhadap pemahaman keyakinan masing-masing agama9. Berdasarkan pernyataan Russel terkait dengan perubahan paradigma dan metodologi problem keagamaan, ini artinya bahwa Russel memiliki pengalaman keagamaan dalam beberapa wilyah teologi, misalnya Islam di Amerika Utara, sebagaimana dikatakan Muhammad Abdul Rauf "The Puture of The Islamic Tradition North America, kemudian Islam di Australia juga jelaskan oleh Abdullah Saeed sebagai konsekwensi Islam minoritas dalam menghadapi kehidupan modern, memerlukan paradigma baru dalam menyeseuaikan diri dengan menghadapi pergumulan manusia secar liberal.

Selain itu, banyak pula peneliti keislaman (insider) misalnya Nasr Hamid Abu Zaid yang menjelaskan dengn kondisi keislaman di Arab Saudi dalam bukunya “Ishkaliyat al-Ta'wil, sebagai tawaran dalam proses perubahan pemikiran Islam yang ada di Arab. Begitu pula Islam Afrika seperti diungkapkan oleh Aminah Wadud "perlu ada metode kesetaraan gender (metode Humanietic

${ }^{7}$ Peter Antes, et. al. dalam bukunya "New Approaches to the Study of Religion: Textual, Comparative, Sociological, and Cognitive Approaches, Walter de Gruyter, Auditan, (Oxford: Oxford University Press, 2004), h. iv

${ }^{8}$ McCutcheon T. Russell adalah Profesor dan Ketua Departemen Studi Agama di Universitas Alabama. Disamping itu beliau juga memahami teori mitos dan ritual, sejarah studi yang didanai Amerika Serikat (Oxford University Press, 1997),

(http://www.as.ua.edu/rel/mccutch.html, di akses 22 Januari 2011)

${ }^{9}$ Russell T. McCutcheon, The Insider/Outsider, Problem in the Study of Religion London and ew York Cassel, 1998), h. 15 
of Gender Justice $)^{10}$. Begitu pula pemikiran Fazlur Rahman, bahkan Rahman mengatakan bahwa metode keagamaan masyarakat perlu penyesuaian dengan kondisi lokal dan geografis sehingga tidak mengalami ketinggalan dan terpinggirkan. Hal yang sama juga dikemukakan oleh Seyyed Husein Nasr, langkah apapun yang diambil untuk membawa pemahaman yang lebih baik Islam di Barat akan saling menguntungkan baik bagi dunia Islam maupun Barat, dua belahan dunia yang dominan ini saling berkaitan dengan cara yang tidak selalu jelas namun yang memeluk kehidupan rohani, artistik dan intelektual, serta kegiatan dalam arena politik dan ekonomi, atau semua yang merupakan permadani dari kehidupan batin dan sejarah manusia seperti diungkapkan dalam matriks ruang dan waktu. ${ }^{11}$

Kalu kita memaknai apa yang telah dikritisi oleh Russel sebenarnya sangat beralasan, sebab metodologi dalam memahami agama itu tidak hanya cukup menggunakan beberapa metode, apalagi hidup di tengah-tengah pergumulan dan perkembangan ilmu pengetahuan secara modern sebagaimana dalam kutipannya berikut, Critical Trend in the Study of Religion in the United States oleh Russel T. McCutcheon ${ }^{12}$ sebenarnya Russel merasa

${ }^{10}$ Rangkaian Pemikiran di atas pemunils kutip dari beberapa usulan dalam dskusi kelas dan makalah-makalah revisi telah didiskusikan sebelumnya. Dengan mata kuliah Metodologi Studi Islam, oleh Amin Abdullah tahun 2010. 1985), h. 8.

${ }^{11}$ Seyyed Husen Nasr, Traditional in the Modern World, Perss London,

${ }^{12}$ Russel T. McCutceon menyatakan, Despite the feet that the academic study of religion is well over one hundred years old in Europe and in is most recent from has been institutionally sectioned in North America for nearly forty years. the problem of developing useful theories and methods and by means of theses, a secure institutional identity as fart of the human sciencecontinues to plague the field in the U.S. I say continues to plague to bignipy that the current North American. Pidd is characterized by a long standing split, between theologian and liberal, humanoids, on the hand, and these more inclined to study religion in a social scientific manner on the other. (New Approaches to the Study of Religion: Textual, Comparative, Sociological, and Cognitive (Tanggapan Ruse, Critical Trend in the Study of Religion in the United States by Russel T. McCutcheon, 2004), h. 317. 
prihatin terhadap penganut agama di Amerika sehingga ia mengkeritisi terutama bagi mereka yang memahami agama namun tidak mampu menyesuaikan diri dengan budaya Amerika, akhirnya mereka termarjinalkan oleh lingkungan sosial. Russel kembali mengatakan "kurang lebih seratus tahun studi akademik agama di Eropa dan Amerika Utara selalu mengalami perubahan, dan paling berpengaruh terhadap institusinya, khususnya di Amerika Utara mengalami berbagai masalah keagamaan teruatama masalah pengembangan teori ${ }^{13}$

Dari rangkaian teori dan pemikiran dapat dianalisis bahwa, perubahan dan perkembangan Islam di berbagai wilayah sebenarnya memerlukan berbagai variasi metodologi, tidak cukup kalau hanya menggunakan metodologi normatif sebagai rujukan, sebagaimana terjadi dibeberapa agama sebelumnya dalam tanda petik (") yang mempertahankan kitab suci sebagai legitimasi dalam perbagai keputusan, pada akhirnya akan mengalami pergeseran, kemunduran, bahkan ditinggalkan oleh pengikutnya.

\section{METODOLOGI PENDEKATAN AGAMA}

Sebelum kita mengkaji lebih jauh terhadap beberapa metodologi yang digunakan para intelektual dari berbagai kalangan pengkaji dan peneliti agama, mungkin lebih awal kita akan memaknai metodologi sebagai sebua pendekatan yang berkaitan dengan kondisi sosiokultural dalam lingkungan di berbagai wilyah. Peter Antes et.al. mengemukakan beberapa terma alternatif sebagai langkah metodologi dalam memahami dan menyesuaikan eksistensi agama-agama dalam penelitian agama modern, sebagaimana diuraikan pada bagian berikut.

\section{Pendekatan Sosiologi dalam Agama}

Agama merupakan hal yang sangat penting sebab persoalan-persoalan sosial kemasyarakatan, selalu terkait dalam kehidupan manusia sebagai bentuk interaksi. Karena itu problem

\section{${ }^{13} \mathrm{Ibid}$.}


of religion yang berkaitan dengan perubahan sosial serta ciri masyarakat secara religius memberikan arti yang sangat luas sehingga secara sosiologis harus dipahami dari berbagai aspek sebagaimana dikemukakan oleh Robet N. Bellah dalam sebuah teorinya tentang tiga tipe utama kajian agama yang dilakukan oleh para sosiolog dalam masyarakat. Pertama, mereka mengkaji agama sebagai sebuah persoalan teoritis yang utama dalam upaya memahami tindakan sosial. Kedua, mereka menelaah kaitan antara agama dan berbagai wilayah kehidupan sosial lainnya, seperti ekonomi, politik dan kelas sosial. Ketiga mereka mempelajari peran, oraganisasi dan gerakan-gerakan keagamaan. ${ }^{14}$

Seperti halnya "Rousseau dan Imanuel Kant kedua tokoh ini lebih percaya pada sebuah agama secara umum, dan mereka melandaskan keyakinan keagamaan lebih pada watak manusia yang suka pada simbol (Rousseau) atau pada diktum-diktum pengalaman etika (Kant) atas dasar argumen-argumen yang murni kognitif ${ }^{15}$ artinya kedua tokoh ini memandang bahwa seorang agamawan tidak berarti apa-apa dalam diri ketika tidak mengamalkan ajaran agamanya sehingga menjadi parameter dalam keagamaan. Begitu pula Emile Durkheim dalam bukunya yang terkenal "The Elementery Forms of Religious Life (1976) bagi mereka agama harus selalu eksis karena semua sistem sosial membutuhkan integrasi, kemudian apa yang sama dalam hal dan kerjanya serta fungsi-fungsi integratif yang dijalankan semua agama sebagai sistem sosialnya. ${ }^{16}$

Karena itu agama tidak dapat memberikan jaminan keabadian dan keselamatan apa bila bagi penganutnya tidak memaknai secara ritual formal setiap waktu. Para sosiolog melihat bahwa eksistensi keagamaan dalam masyarakat merupakan suatau

\footnotetext{
${ }^{14}$ Robert N. Bellah, Beyond Belief Esei-Esei tentang Agama di Dunia Modern, (Jakarta Paramadina, 2000), h. 3

${ }^{15}$ Ibid., h. 5

${ }^{16}$ Pip Jones, Pengantar Teori-Teori Sosial dari Teri Fungsionalisme Hingga Post Modernisme, (Jakarta Yayasan Obor Indonesia, 2009),h. 57
} 
kenyataan yang harus dikaji secara empiris". Bryan S. Turner "jika agama sebagai institusi sosial dapat memenuhi beberapa kebutuhan akan fungsi-fungsi sosial maka agama-agama yang terlembaga sebagai bagian dari pabrik sosial akan berimplikasi pada relasi sosial ${ }^{17}$ mempunyai arti yang sangat luas bahwa setiap lembaga keagamaan memiliki tanggung jawab sosial untuk membangun kesadaran masayarakat dan bertanggung-jawab secara individu maupun sebagai komunitas masyarakat. Sementara itu dalam pandangan Max Weber, manusia yang hidup dalam berbagai masyarakat memiliki teori-teori mereka sendiri mengenai dunia mereka, tetapi keadaan mental tidak selalu berhubungan dengan realitas struktural ${ }^{18}$ meskipun Weber mencoba mengkritisi konsep strukturalisme yang berkembang di Barat yang sangat berpengaruh terhadap pola religiusitas masyarakat.

Kemudian Russel T. McCutcheon dalam penyataannya pada saat ia bersama temannya di Universitas Toronto Kanada tahun 1990. Bahwa kontroversi studi agama sebenarnya hanya persoalan metodologi oleh karenanya harus kembali dibicarakan secara terbuka dan objektif (the fail to identifity for their students the complex and consted theoretical, definitional, and metodological issues that have shaped the field over the past 100 years $)^{19}$ dia menjelaskan bahwa kompleks permaslahan yang terdapat pada lembaga studi masing-masing agama sebenarnya suda berjalan sekitar seratus tahun yang lalu, yakni terutama masalah-maslah indentitas, teori dan difinisi sebagai persoalan pokok. Seiring dengan itu Amin Abdullah disebuah pengantarnya menjelaskan "dalam wilayah diskursus keilmuan agama, semua persoalan keagamaan yang diperbincangkan dan diperdebatkan dalam

\footnotetext{
${ }^{17}$ Bryan Turner, Agama dan Teori Sosial, Rangka Fikir Sosiologi dalam Membaca Eksistensi Tuhan diantara Gelar Idiologi-Idiologi Kontemporer, (Yogyakarta, Ircisod, 2003),70

${ }^{18}$ Pip Jones, Pengantar Teori-Teori Sosial, dari Teori Fungsionalisme Hingga Post Modernisme, Jakarta, Yayasan Obor Indonesia, 2009), h. 113.

${ }^{19}$ Edited By Russel T. McCuteheon, The Insider /Outsider..., vii.
} 
masyarakat seolah-olah semuanya masuk dalam kategori applied sciences yang bersifat ta'abbudiy-ekslusif. ${ }^{20}$ Kenyataanya, banyak di kalangan ahli agama memahami agamanya berdasarkan aspek normatif-teolgis dan tidak dapat diperdebatkan lagi, padahal secara sosiologis persoalan keagamaan selau mengalami perubahan seiring dengan ruang dan waktu (fleksibel).

Dengan cara pandangan seperti itu, fenomena keberagamaan manusia perlu didekati, diteliti, dipahami, dikritik, bahkan dinikmati melalui cara pendekatan keilmuan. ${ }^{21}$ Misalnya Islam Arab, berbeda cara pandang agamanya dengan Islam Amerika, begitu juga agama lain, sebab di situ terjadi perbedaan iklim dan geografis, termasuk psikologis, sehingga apa yang sebanarnya dikatakan oleh Muhammad Abdul Rauf terhadap eksistensi Islam di Amerika Utara kasusnya seperti itu dalam bukunya. The Muslim community in North America. Berkaitan dengan itu John L. Esposito menjelaskan "kebebasan Barat memungkinkan pemuka agama intelektual dan aktivis Islam menjadi suara utama dalam perubahan religius, sosial dan politik ${ }^{22}$ sebenarnya apa yang dikemukakan John L. Esposito merupakan ungkapan pengalamannya ketika melihat umat beragama yang minoritas dalam beberapa wilayah di negeranegara maju termasuk Amerika dan Eropa lainnya. Berkaitan dengan itu penulis mencoba menguraikan berdasarkan analisis teori sosial sebagai paradigma pikir dalam metodologi penelitian agama-agama (study of religions), termasuk merespon permasalahan keagamaan dewasa ini.

\footnotetext{
${ }^{20}$ Moh. Shofan, Jalan Ketiga Pemikiran Islam, mencari Solusi Perdebatan Tradisionalime dan Liberalisme, Jogyakarta IRCiSoD 2006), h. 7.

${ }^{21}$ Ibid.

${ }^{22}$ John L.Esposito, Masa Depan Islam, diterjemahkan dari judul aslinya"The Fiture of Islam, Firts Edition" Oxford University Press, 2010 (Bandung Mizan, 2010), h. 65.
} 


\section{Gambar I. Bagan Paradigma Analisis Teori Sosiologi Agama Modern}

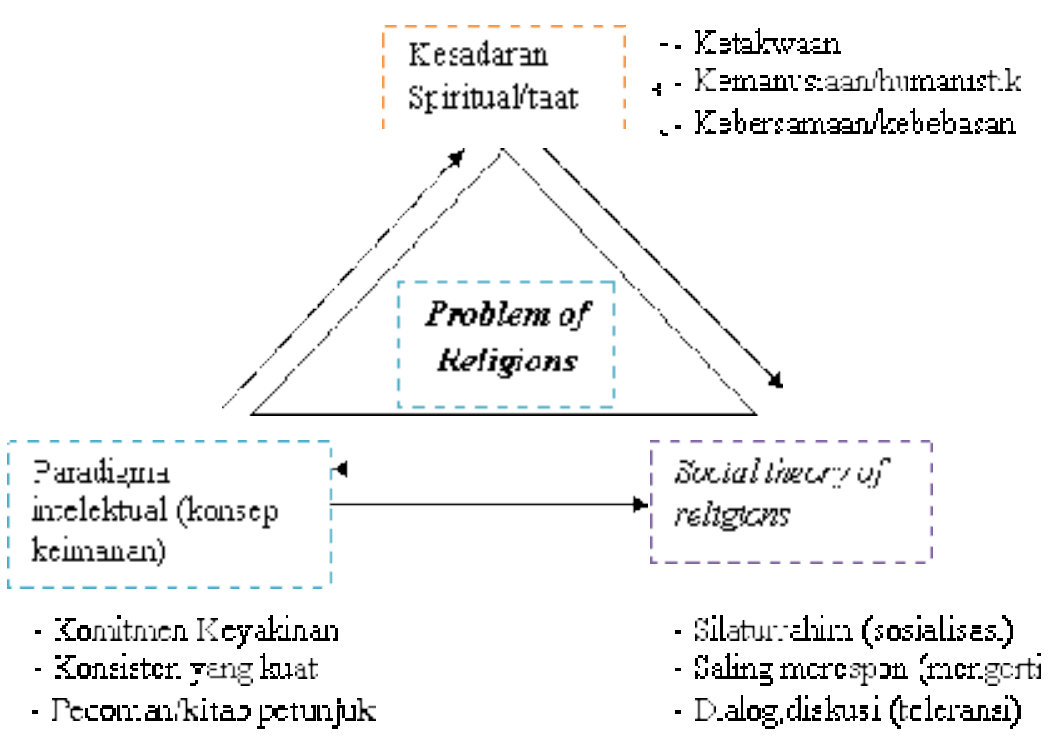

Bagan ini merupakan refleksi pemikiran hasil seminar dan saran dari peserta pada suatu forum diskusi. Disamping itu Russel T. McCuteheon dan Fazlur Rahman mengingingkan perubahan paradigma keagamaan, terutama mereka yang minoritas dalam kelompok mayoritas. Perlu kita sadari bahwa keinginan perubahan tradisi keagamaan terhadap lingkungan sosial tidak berarti normativitas teologi yang dipahami harus diubah, melainkan metode dan pendekatannya yang diubah sehingga melahirkan ketenangan dalam menjalankan ibadah dan akhirnya mencapai ketenangan spiritual.

\section{Pendekatan Antropologi dalam Agama}

Sebelum kita mengkaji secara mendalam tentang agama dalam pandangan antropologis (antropology of religion) secara umum penulis kemukakan makna antropolgi. Sebenarnya ilmu ini banyak membicarakan masalah manusia secara utuh, misalnya bagaimana perilakunya, karakter dan keturunanya, dan sebagainya. Untuk lebih jelasnya, akan kita lihat pemikiran 
berikut. Penekanan antropologi lebih pada beberapa aspek antara lain: aspek sejarah kapan terjadinya dan perkembangan manusia sebagai mahkluk sosial, kemudian aspek aneka warna manusia dipandang dari segi ciri-ciri tubuhnya, aspek penyebaranya dan warna bahasanya, serta aspek perkembangan dan ragam budayanya, termasuk aspek suku dan dan tradisi yang dianutnya. ${ }^{23}$ Dalam perkembangan selanjutnya ilmu ini selalu berevolusi berdasarkan eksistensinya termasuk kemampuannya beradaptasi dan merespon perilaku dan perubahan masyarakat sehingga para ahli menemukan kembali beberapa istilah baru dalam ilmu antropologi seperti: antropologi fisik, antropologi sosial, antropologi, ekonomi, antropologi politik, antropolgi budaya termasuk antropologi Agama. ${ }^{24}$ Di sinilah mungkin kita akan masuk dan memahami konsep-konsep teologi dan religion secara antropologis.

Seperti Marcel Mauss seorang penulis yang terkenal kurang lebih empat puluh tahun lalu: mengatakan perkembangan antropologiy dan Sosiologi selalu seiring dimana-mana orang akan mengkaji dan dijadikan petunjuk terutama dari ahli bahasa ${ }^{25}$. Kemudian dia menambahkan kembali "the close methodological analogy which exists between the two disciplines imposes a special obligation of collaboration upon them". Maksudnya kira-kira seperti ini analogi kedua metodologi ini sebagai disiplin ilmu sangat memberikan pengaruh secara dekat dan bahkan bisa berkolaborasi ${ }^{26}$. Maksudnya dua ilmu ini bisa dipertemukan sebagai metode dalam memahami konsep keagaman. Sebenarnya apa yang dikatakan pendekatan baru dalam buku "New

\footnotetext{
${ }^{23}$ Koentjaraningrat, Pokok-Pokok Antropologi Sosial, penulis kutip dari Nursyam, Mazhab-Mazhab Antropolgi (Jakarta, Dian Press, 1990), h. 1.

${ }^{24}$ Nur Syam, Mazhab-Mazhab Antropologi (Yogyakarta: LKiS, 2009), h. 8.

${ }^{25}$ Claude Levi-Strauss, Structural Analysis in Linguistics and in Anthropoly, Translated from the French by Claire Jacobson and Brooke Grundfest Schoepf Basic Books Inc. Publishers (New York United State of America.1963), h. 31-32.

${ }^{26}$ Ibid.
} 
Approaches to the Study of Religion: atau (Pendekatan Baru untuk Studi Agama, Tekstual, komparatif, sosiologis, dan pendekatan kognitif), dalam rangka merespons perkembangan keagamaan akhir-akhir ini kadangan-kadang kita hanya menggunakan salah satu disiplin keilmuan pada hal semuanya bisa terkait atau (saya meminjam istilah Amin Abdullah) interkoneksi dan interdisipliner". Para Antropologi di sisi lain mengatakan, can bring to the attention of the linguist customs, prescriptions, and prohibitions that help him to understand the persistence of certain features of language or the instability of terms or groups. Maknanya: para antropologi merasa prihatin atas kebiasaankebiasaan ahli bahasa mempersepsikan dan membuat aturan/istilah yang susah dipahami para kelompok-kelompok tertentu. Kemudian "But Linguists and anthropologists follow their own paths in the pendently. ${ }^{27}$ Para ahli bahasa dan ahli antropologi mengikuti jalan mereka sendiri secara independen, dan tidak pernah berhenti berkomunkasi satu sama lain atas temuan-temuan mereka. Disinilah kita bisa memahami bahwa perubahan metodologi dalam rangka merespon perubahan sosial keagamaan tidak hanya cukup menggunakan satu konsep metodologi saja. Sebagaimana Russel T. McCutheon memberikan contoh Amerika Utara dan Eropa setiap saat ada perubahan dalam struktur pemahaman dan budaya masyarakat. Sebab kedua wilayah ini memiliki karakter dan budaya yang berbeda-beda, maka secara antropologis harus dilakukan pendekatan sebagai metode atau cara memahami karakter dan perilaku masyarakat dan agamanya secara keseluruhan. Sebagaiman dikemukakan oleh Muhammad Abdul Rauf. "The Muslim Commonity in North Amerika" atau komunitas muslim Amerika Utara telah mengalami pergeseran nilai dan budaya ${ }^{28}$.

Peter Antes mengatakan "A Survey of New Approaches to the Study of Religion in Europe" berdasarkan hasil survei studi

${ }^{27}$ Ibid.

${ }^{28}$ Muhammad Abdul Rauf, Prevektives In Islamic Studies...., h. 445. 
agama di Eropa salah satu karakteristik paling mencolok dari Eropa secara keseluruhan adalah budaya ${ }^{29}$, terutama di universitas/yang susah mengekspresikan bahasa dan budaya sebagai tradisi studi keagamaan. Karen Amstrong dalam pengantarnya menjelaskan "gerakan pembahruan biasanya terjadi dalam priode pembahruan kultural atau sesuda bencana besar dalam politik ketika jawaban-jawaban lama tidak lagi memadai dan para pembaharu berusaha memutkhirkan tradisi lama supaya dapat memenuhi tantangan zaman ${ }^{30}$ ilustrasi tersebut dapat dipahami dengan kondisi psikologis, sosiologis, dan antropologis umat beragama di berbgai negara di era modern ini. Doktrin normativitas dan konservatisme paham teologi membuat mereka sulit beradaptasi dengan lingkungan yang berada. Untuk itu penulis membuat alur pikir secara antropologis dan kultural sebagaimana diilustrasikan pada gambar 2 .

Bagan tersebut menunjukkan bahwa dalam pendekatan antropologi kelompok peneliti (outsiders) dan perilaku keagamaan harus memahami bahwa dalam wilayah tertentu pasti memiliki budaya dan tradisi yang berbeda-beda. Oleh karenaitu diperlukan konsep dan perilaku dalam rangka menyesuaikan karakter keberagamaan. Ekistensi Islam misalnya yang ada di beberapa wilayah belahan dunia tentu sangat berbeda dengan Islam yang ada di Arab atau Timur Tengah.

\footnotetext{
${ }^{29}$ Peter Antes, et.al., New Approaches...,h. 43.

${ }^{30}$ Karen Armstong, pengantar dalam buku berjudul Masa Depan Islam karangan John L. Esposito, (Op,Cit), 12. Dia adalah penulis yang sangat populer dalam berbagai literatur yang ditulis dan dijadkan rujukan akademik secara universal diberbagai perguruan tinggi dan salah satu bukunya yang terkenal adalah Sejarah Tuhan, diterjamahkan di Indonesia dan diterbitkan oleh Mizan tahun 2001.
} 


\section{Gambar 2. Bagan Paradigma Analisis Antropologi Agama Modern}

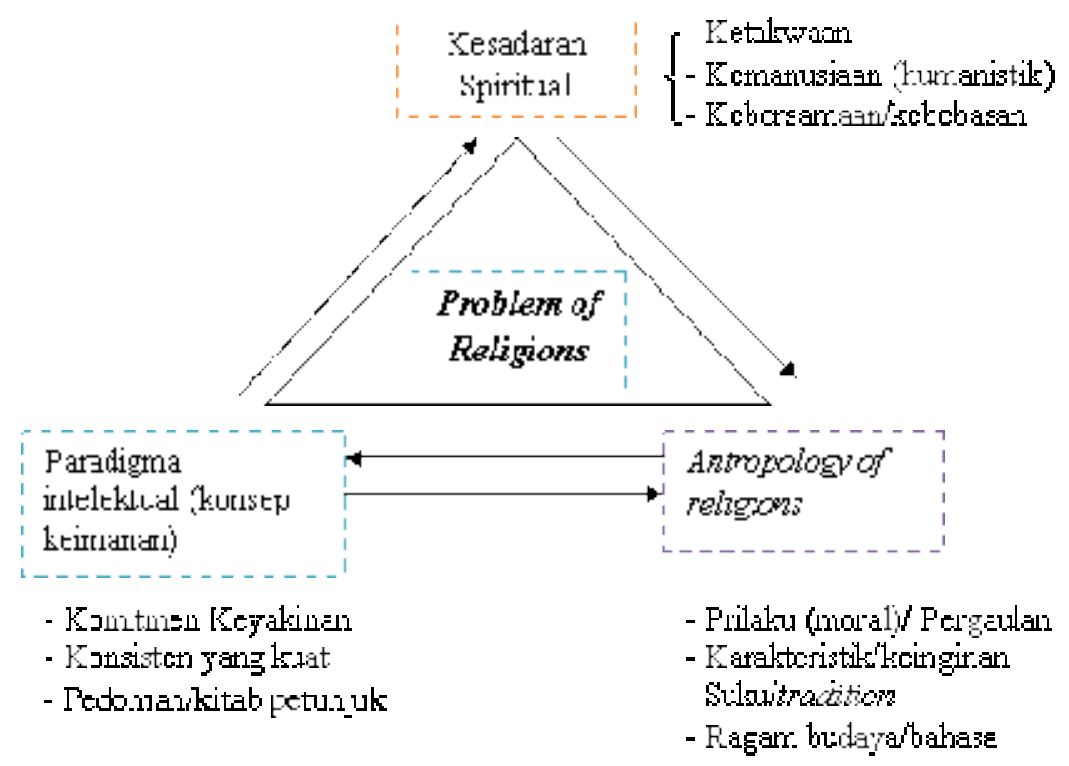

Sebenarnya Russel T. McCutcheon, menginginkan perubahan pola perilaku dan karakter keberagamaan manusia dalam wilayah tertentu, sehingga ia tidak merasa terasing dan termarjinalkan dengan lingkungannya.

\section{Comparative Approache of Religion}

Mengawali dari sebua naratif yang dikemukan Austin Cline dalam bukunya "Global Theology Comparative Study of Religion, Faith, and Gods ${ }^{31}$ " Filsuf dan teolog telah membandingkan berbagai agama untuk menjelaskan kedua persamaan dan perbedaan mereka. Hari ini, meskipun, ada sesuatu yang disebut "teologi global" atau

${ }^{31}$ Philosophers and theologians have compared various religions to elucidate both their similarities and their differences. Today, though, there is something called "global theology" or "world theology" which is the attempt to compare two or more religious traditions from the perspective of one in particular. Also sometimes called comparative theology," it is often a selfconsciously partisan enterprise pursued by theologians with specific faith commitments (and agendas). 
"teologi dunia" yang merupakan upaya untuk membandingkan dua atau lebih tradisi keagamaan dari perspektif orang tertentu. Juga kadang-kadang disebut "teologi komparatif," adalah seringkali perusahaan sendiri sadar partisan dikejar oleh teolog dengan komitmen iman tertentu (dan agenda) ${ }^{32}$.

Dalam literatur Barat, perbandingan agama sebenarnya sudah ada semenjak Yunani Kuno, hanya saja puncak dari perkembangan studi perbandingan agama ini menjadi sebuah disiplin ilmu, katanya, lahir di Barat dengan diprakarsai oleh Frederich Max Muller, sehingga di Barat dia dijuluki The Father of Comparative Study of Religion ${ }^{33}$. Saymour Cain dalam artikelnya berjudul "Study of Religion; History of Study" Dia menjelaskan mulai abad sebelum masehi (Yunani kuno) para filosof seperti Aristoteles, Plato, Anaximenes, Phitagoras dan yang lainnya, menjadi peletak dasar cikal bakal disiplin ilmu ini. Tentu suatu ilmu tidak akan sampai kepada suatu zaman, mengalami loncatan zaman, untuk kemudian sampai pada beberapa abad berikutnya tanpa ada rantai (miss ling). Kalau dilihat dari sejarah awal abad Masehi, ilmu pengetahuan mengalami stagnanisasi, hal tersebut dikarenakan adanya pengekangan dari suatu lembaga yang mengatasnamakan agama dan Tuhan. Masyarakat ketika itu, ditekan terus menerus untuk tidak berkreatif, mereka dipaksa untuk tunduk dan patuh terhadap agama mereka. Sementara Rommen, Edward menjelaskan dalam a comparative study of world religions ${ }^{34}$ Dalam studi perbandingan agama, kategori agama Ibrahim terdiri dari tiga agama monoteistik, Kristen, Islam

\footnotetext{
${ }^{32}$ Austin Cline, "Global Theology Comparative Study of Religion, Faith, and Gods", European Journal of Science and Theology, March 2006, Vol.2, No.1, h. 47-54.

${ }^{33}$ Ibid.

${ }^{34}$ Rommen Edwar, A Comparative Study of World Religions, Journal International Posted on: 04/25/2003.
} 
dan Yahudi, yang mengklaim Abraham (Ibrani Avraham אַבְרָָהָם Arab Ibrahim (إبر اهيم) sebagai bagian dari sejarah suci mereka ${ }^{35}$.

Sementara dalam Encyclopedy of Religion yang menjadi rujukan para sarjana-sarjana Barat (orientalis) dalam bidang ilmu perbandingan agama, meskipun sebenarnya secara historis bahwa ilmu ini telah dipopulerkan sarajana dan ulama muslim jauh sebelum Max Muller. Katakanlah al-Biruni, Abu Isa al-Warraq, AlSyahratsani dalam buku al-Milal wa al-Nihal, Ibnu Hazm juga menulis risalah tentang agama-agama, termasuk Ibnu Taimiyah. Meskipun hanya sedikit dari kalangan intelektual Barat secara objektif mengakui keilmuan Islam.

Secara ontologis dan epistemologis perbandingan agama merupakan bagian organik yang tidak dapat dipisahkan dari realitas kehidupan. Oleh karena itu, sebagai konsekuensi praktisnya, baik yang secara terang-terangan maupun terselubung nyaris tidak terhindarkan dan terjadi pada semua lini kehidupan termasuk "teologis of religions, evalution atau perubahan yang merupakan keniscayaan, bukanlah penilaian yang bebas dilakukan sesuai dengan kemauan 'subjektif penilai (outsider)'akan tetapi penilaian ini tentu harus tunduk pada kaidah-kaidah, prinsipprinsip dan metodologi yang vallid dan dapat diverifikasi secara logis dan rasional. Untuk itulah Russel T. McCutcheon mengkritisi berbagai metodologi yang dikemukakan oleh Peter Antes (et.al.) kaitannya dengan Problem of Religin. Dalam bukunya New Approaches to Study of Religion, sebab perubahan perspektif keagamaan masayarakat dalam konteks modern tidak cukup kalu kita hanya melihat dari sisi sosial, budayanya apa lagi hanya membandingkan maka harus dilihat secara komprehensip, oleh karena itu di sini menjadi dimungkinkan adanya penilaian (value judgment) yang objektif atau kajian deskriptif maupun kritis sebagai pendekatan dalam perbandingan agama modern. Deskriptif, kritis dan objektif tiga istilah yang tidak terpisahkan,

\footnotetext{
${ }^{35}$ Comparative of Religions, http://www.google.co.id/com 31-10-2010.
} 
masing-masing memiliki fungsi dan tujuan dalam mencapai kepuasan ilmu pengetahuan dan intelektual. Karena itu kajian teologi keagamaan sebenarnya berorientasi akademik sebagai lembaga ilmiah yang memiliki ligitimasi pengetahuan yang tinggi. Oleh karenanya perubahan dan penambahan metodologi pengkajian dan penelitian agama merupakan hal yang sangat diperlukan apa lagi di era ini.

\section{Cognitve Approach of Religion}

Religious studies today are witnessing new developments as a result of the application (studi agama saat ini sedang menyaksikan perkembangan baru sebagai akibat penerapan metode kognitif penomena agama. Sebagai wujud dari hasil penelitian para ahli teologi keagamaan (theological perspective religion) ${ }^{36}$ dari penelitian ini menunjukkan beberapa peluang metodologis untuk yang lebih baik, dapat dipahami dan sekaligus bisa diperaktekkan sangat terkait dengan agama sebagai normatif propan, dalam memberikan jaminan keselamatan bagi penganut agama masingmasing, understanding of biblical and theological issues and, at the same time ${ }^{37}$, pemahaman dan isu-isu teologis alkitabiah, meskipun pada saat bersamaan masing-masing memeperlihatkan kelemahan.

Ilmuwan sosial, Chassidim dari Williamsburg, menjelaskan "But the difference is that, in tune with their unit of analysis, the individual, cognitive treat these cases as illustrative of common features while social scientists look for differences. Maksudnya mereka selaras dengan analisis, individu, kognitif mengobati kasus sebagai ilustrasi dari fitur-fitur umum sementara ilmuwan sosial mencari perbedaan. Tidak ada yang salah dengan semacam

\footnotetext{
${ }^{36}$ Luís Oviedo, Eropa Jurnal Sains dan Teologi, March 2006, Vol.2, No.1, 47-54 Maret 2006, Vol.2, No.1, h. 47-54.

${ }^{37}$ Theology Faculty, Pontifical University Antonianum, Via Merulana 124, Fakultas Teologi, Universitas Antonianum Kepausan, Via Merulana 124, 00185 Roma, Italy 00185 Roma, Italia (Received 2 December 2005) (Diterima 2 Desember 2005).
} 
ini makro-perbandingan, tetapi, untuk semua yang sangat menarik dan kreatif, yang mengalami berbagai kesulitan dalam menggambar batas putaran unit analisis, dan tidak hanya di dunia global saat ini. The cognitive approach provides a strategy ${ }^{38}$. Pendekatan kognitif menyediakan strategi untuk memahami berbagai persoalan-persoalan umat dan agama. David Hume, dalam bukunya "The Natural History of Religion pada halam 29 Pendekatan kognitif klasik dengan agama menyatakan bahwa kepercayaan pada tuhan, model-pemahaman diri manusia, timbul dan bertahan karena mereka menyadari dan mengerti bahwa secara alamiah memiliki keterkaitan dengan Tuhan dan alam semesta sebagai wujud ciptaannya yang harus direnungi dan dirasakan atau masuk akal.

Sebenarnya kalau kita mencermati apa yang telah digagas oleh Peter Antes (et.al.) kaitannya dengan beberapa pendekatan terhadap problem keagamaan memang sangat terkait dengan perkembangan dan pola pikir manusia dizaman modern, sebab agama tidak hanya cukup dipahami, berdasarkan realitas sosial dan perbandingan melainkan juga harus dipahami secara kognitif, dalam hal ini perilaku keagamaan. Secara realistis, apa yang telah dikemukan oleh Russel T. McCutcheon bahwa menghadapi kehidupan ini memerlukan pendekatan multikultural, terutama hal-hal yang berkitan dengan problem keagamaan. Apa yang disebeut dengan kekerasan agama dan fundamenalisme agama sebenarnya hal ini sangat terkait dengan kondisi dan pendekatan yang hraus dikgunakan untuk merespon hal tersebut, di sinilah Peter antes dan Armin G.W. Geertz menggunakan pendekatan Kognitif agama disamping juga menggunakan pendekatan lain.

Pada umumnya, agama secara signifikan mempengaruhi perilaku individu dan merupakan eksistensial seorang individu

\footnotetext{
${ }^{38}$ Ibid.

${ }^{39}$ David Hume, dalam bukunya "The Natural History of Religion, http://www.google.co.id/com 31-10- 2010.
} 
dengan menggunakan perasaannya dan psikologi kejiwaaannya. Sebagaimana dialami oleh John L. Esposito setelah memberikan ceramah di Afrika Selatan seperti kutipan berikut: "setelah saya memberikan ceramah, kemudian seorang cendikiawan muda Muslim bertanya kepada saya kalimatnya begitu panjang dengan mengatakan "dengan demikian Prof. Esposito, kami mengagumi peran anda yang luar biasa sebagai ahli Islam; kami menghargai pemahaman anda mengenai Islam dan usaha anda dalam meningkatkan pemahaman Islam di Barat, tetapi tentu saja hal ini tidak mengubah fakta bahwa anda bukan Muslim dan anda tetap akan masuk neraka "separo hadirin tersenyum menyetujui pendapatnya separo lainnya terlihat malu karena dia terangterangan membeberkan sikap mereka ke muka saya ${ }^{40}$

Narasi tersebut secara kognitif sangat objektif dan memang intinya seperti itu adanya, namun secara intelektual seharusnya lebih ilmiah ketika menggunkan pendekatan psikologi dan rasionalitas terhadap eksistenasi seseorang dalam membicarakan kebenaran secara ilmiah, sebagai inteletual bahwa kebenaran itu tidak mesti dari mulut manusia bahkan mungkin dari makhluk lainnya nah disinilah sebenarnya fungsi dan peranan kognitif para peneliti dan penganut agama. Agama secara signifikan berpengaruh terhadap perilaku individu dan masyarakat sehingga agama dalam pendekatan kognitive akan memberikan pengaruh bagi orang-orang yang ingin memahami bagaimana sebenarnya alam semesta, manusia dan tuhan sebagai pusat eksistensi, maka disini perlu toleransi, kerja sama saling memberi dan menerima.

\section{PENUTUP}

Pemahaman Keagamaan Russel T. McCutheon, Tokoh yang kritis dalam melihat dan merespon persoalan agama, memberikan pandangan bahwa dalam menghadapi kehidupan yang serba canggih dan modern, perlu digunakan berbagai multi

${ }^{40}$ John L.Esposito, Masa Depan Islam..., h. 262. 
pendekatan sehingga menghasilkan sebuah teori yang bisa dipahami dan diterima oleh seluruh umat beragama. Disamping itu tidak ada yang merasa termarjinalkan dari struktur kehidupan sosial sebab miniatur dunia yang dihuni oleh setiap manusia di jagad ini kadang-kadang membuat dirinya merasa lebih berkuasa dari penguasa yang sebenrnya.

Berbagai teori yang dikemukan Peter Antes et.al. sebagai bentuk pendekatan dalam memahami perilaku keagamaan masyakat (insider dan outider) dewasa ini, sebenarnya suatu kesadaran intelektual yang harus dijalankan setiap individu akademik sehingga akan semakin tampak sebuah teori dan pendekatan baru secara terbuka dan objektif. Demgam demikian, tidak ada yang merasa dirugikan dalam beragama sekaligus sebagai warga minoritas dalam eksistensi agama mayoritas, di berbagai wilayah belahan dunia ini.

\section{DAFTAR PUSTAKA}

Abdul Rauf, Muhammad. at. al. Insider/Outsider Prevektives In Isamic Studies (UIN Sunan Kalijaga Jogyakarta. 2009)

Abdul Rauf, Muhammad, at. al.. 1983. The Muslim Community in North Amerika, Earle H. Waugh, Baha Abu-Laban Regula Qureshi.

Antes Peter, et. al. New Approaches to the Study of Religion: Textual, Comparative, Sociological, and Cognitive Approaches. Walter de Gruyter, Auditan, Oxford University. 2004)

Austin Cline, Austin. Global Theology Comparative Study of Religion, Faith, and Gods" (European Journal of Science and Theology, March 2006, Vol.2, No.1, 47-54

Bellah, N. Robert. 2000. Beyond Belief Esei-Esei tentang Agama di Dunia Modern, Jakarta Paramadinah, 2000

Edwar, Rommen. a comparative study of world religions Jurnal Internasioal Posted on: 04/25/2003 
Esposito, John L. 2010. Masa Depan Islam, diterjemahkan dari The Fiture of Islam, Firts Edition. Oxford: Oxford University Press. Bandung: Mizan.

http://www.google.co.id/com David Hume, dalam bukunya "The Natural History of Religion, 29-10- 2010

http://www.google.co.id/com Comparative of Religion, 31-102010

Jones, Pip. 2009. Pengantar Teori-Teori Sosial dari Teori Fungsionalisme hingga Postmodernisme. Jakarta: Yayasan Obor Indonesia.

Koentjaraningrat. 1990. "Pokok-Pokok Antropologi Sosial" dalam Nursyam, Mazhab-mazhab Antropolgi. Jakarta, Dian Press

Levi-Strauss, Claude. 1963. Structural Analysis in Linguistcs and in Anthropoly, Translated from the French by Claire Jacobson and Brooke Grundfest Schoepf. New York: Basic Books Inc. Publishers.

McCuteheon, Russel T. 1999. The Insaider/Outsider, Problem in The Study of Religion. Lexington Avenus- New York: Prist Published.

Oviedo, Luis. Eropa Jurnal Sains dan Teologi, March 2006, Vol.2, No.1, 47-54 Maret 2006, Vol.2, No.1.

Oviedo, Luis. 2005. Theology Faculty, Pontifical University Antonianum, Via Merulana 124, Fakultas Teologi, Universitas Antonianum Kepausan, Roma, Italia 2, December.

Sou'yb, Joesoef. 1996. Agama-Agama, Besar Dunia. Jakarta AlHusna Zikra.

Shofan, Moh. 2006. Jalan Ketiga Pemikiran Islam, mencari Solusi Perdebatan Tradisionalime dan Liberalisme, Jogyakarta IRCiSoD.

Syam, Nur. 2009. Madzhab-Madzhab Antropologi. Yogyakarta: LkiS. 